\title{
The Analysis of U.S. Curriculum History Turing Development Based on Cultural Angle of View
}

\author{
Ma Jinxia \\ LinyiUniversity, Shandong, Linyi, 276000
}

Keywords: The United States; The history of curriculum; Culture; Turning

\begin{abstract}
Along with the development and progress in all fields of society, the social, economic and political background of schools operation has been changing a lot.These change in all aspects, and the development and progress of the curriculum have a very profound impact. Curriculum reform and social development are synchronous, in the study, we cannot only considerit as curriculum events chronicle, or a radical reaction of former reforms, but to use more long-term vision, analyze and research through the narration of the story,organically link the past and present curriculum knowledge and experience of the problems faced in the development, so that the lessons from the past provide reference to educators education behavior. This paper expounds the connotation of curriculum history studies, reviews the history of American curriculum formation, and analyzes the turningdevelopment history of the U.S. curriculum history.
\end{abstract}

\section{INTRODUCTION}

As early as the 1970 s,there was a social crisis inthe United States, whichplayed a large indirectly effect on the curriculumhistory of sociological study.This period of curriculumstudy was set in the social history, and mainly placed curriculum history studies in the field of social history or the history of education research for discussion. Later in the $90 \mathrm{~s}$, the study of curriculum keeps pace with the Times, from "social" to "culture", and the main purpose is to deal with theincreasingly prominent cultural tension in United States education. The steeringhad a great impact on the development of history of curriculumin the United States.On the one hand, it has a rise effect for the history of the curriculum; on the other hand,it also created new way and space for the practice of thoseU.S. school scholars whose practice space was shrinking.In this case, curriculumhistory study beganfrom theory to practice, and had a bigger development space of cultural and social fields, which provided more wide-area research way for the research ofcurriculum history. Researchof the characteristics of the dominant culture relation history through the adoption of Foucault's method in American schoolsthus effectively promoted curriculum theory to become a cultural criticism practice.

\section{THE CONNOTATIVE ANALYSIS OF CURRICULUM HISTORY STUDY}

Take western history curriculum study for example.At first, curriculum history was seen as a kind of cultural, social and education related history. By 1987,curriculum history began to be seen as subject field study, and the research focusstarted transition from social and historical perspective to the history of evolution of particular school subjects. In 1990, curriculumhistory was regarded as a kind of abstract textbook factor and the main research content was an introduction of curriculum practice history or thought history, appearing in curriculum textbook chapter of history. In 1997, curriculum history was regarded as a case study, mainly on a particular character, curriculum, or the school's contribution in the history or positioning. In 2000, curriculum history was seen as a memorial and oral history, mainly were some interviews view of curriculum history or academic career of some outstanding curriculum scholars. From the development we can define the connotation of curriculum history. From alarge aspect,history of curriculum is a sub domain of education, and from a small aspect, it is a secondary discipline in the field of curriculum, not only for the historydevelopment of a particular curriculumissue research, also involves thetheory structure withinsubject academic field. Theoretical basis of study of curriculumhistory is not legists, 
but the curriculum concept understanding, it takes curriculum as part of social construct to understand. Traditional curriculum research mainly adopts improving society orientation, and it pays more attention to the present and the future reform movement and recent reform effect, paying attention to the analysis of the existing curriculum practice and thought, and the main analysis points of view are society, history and politics and the study of curriculum theory itself is few [1]. Thus, the occurrence of curriculum knowledge is one of the main content of curriculum history research. In general, the significance of the study of curriculumhistory is mainly in the following several aspects: First, under the historical background, a particular period curriculum education form, education method and education objects are discussed; Second, analyze the restrictions of the past curriculum for the present curriculumdevelopment; Three is to studythe past, current, and futurecurriculum relation of curriculum; Four is to use the past practiceto provide the reference for now and future curriculum practice and research; Five is to provide materials for human activities and the research of the motives; Six is to help people better understand the evaluation of curriculum development pattern; Seven is to help people better understand the defined professional and personal life history. History of curriculumis an important part of social history.It not only has the solid foundation of sociology, but also a positive role in promoting knowledge sociology.

\section{THE FORMATION OF THE HISTORY OF CURRICULUM RESEARCH}

Until the 1960 s, American scholars, as core strength, led many famous education reform movements. In 1960, however, the federal science and education institutions, scientists, and military promptedThe Process of Education, which promotedthe rise of curriculum reformcentered with discipline knowledge structure.Discipline experts, education management scholars and education psychologists have replaced the position of curriculum scholars, thus, greatly reduced thesocial influenceofcurriculumhistory study, and curriculumhistory study suffered a great deal of survival crisis.Professional curriculum also faced a precarious state, and is difficult to continue to make important contributions to education development. In order to change this situation,scholars beganvarious forms of theoretical innovation. Schwab put forward "practice" to build curriculum system. MacDonald offered "different imagination" to construct curriculum research system [2]. There are many scholars in response to the challenge of social crisis to promote social progress as the goal, and made a lot of effort in this respect to seek different theory tools for social crisis, and put forward a large number of useful ideas. Huber finally put forward an idea through the adoption of "ideology, control, power", etc. "concepts" to research innovation curriculum, and won the majority of scholars' general agreement that opened a new door for curriculum research [3]. Curriculums at this time were not only confined to the field of sociology science and political field to find a new theory, but also associated with the historical view organically to promote the formation and development of the history of curriculum research.

\section{U.S. CURRICULUM HISTORY CULTURAL TURNING DEVELOPMENT}

With the development of society and the progress of science and technology changes with each passing day, in the $1980 \mathrm{~s}$, the United States used their advantages accumulatedin the Internet, financial, high-tech and service industry areas, first entered "postindustrial society", whichhad played a huge role in promotingthe development of its economy. In the same period, right-wing politicians represented by Ronald Reagan also kept pace with The Times, who actively conformed to the trend of The Times, and put forward the "new liberalism" policy to protect free market, promote personality, and received widespread support [4]. At the same time, the American society mainstreamhadno longer a lot of expectationsfor structural social criticism or revolution, but put hope on individuals having "innovation". In this context, curriculum scholars with political and social criticism orientation, such as Apple, had been under the mainstream's strict criticism, even were forbidden to speak. And the federal government launched "Curriculum Quality Standardization Reform" plan,which easily won the wide support of social mainstream, and got the smooth implementation in the nationwide. A famous scholar of curriculum theory in the $80 \mathrm{~s}$, 
Taylor, proposed a more scientific study evaluation mechanism, and madethe curriculum study attain the position of authority. From these, we can see that once again curriculum theory innovation faced with the hard predicament [5].

After $80 \mathrm{~s}$, the U.S. the drawbacks of the curriculum reformput forward by federal government emerged, while Apple and others still insisted on their critical stance, and on this basis, introduced "cultural studies" field of vision, leading to social tensions education system, which began to affect teachers, culture, and students' daily life.It proposed requirementsfor curriculumhistory study toupdate; in addition, the exploration and innovationprovided a theory of motivation for the rise of curriculum history. From the perspective of the research, the research reform direction on the history of American curriculum is from "social" to "culture". In 1989, historian Lin hunt created "New Culture"and heargued that since the $1980 \mathrm{~s}$, the story of theoretical research was defined asthe turning point of "social theory" to "new culture" change, which laid the "cultural turn"in the study ofhistorical position [6]. In 2002, Lin hunt made clear that "culture" instead of "society" was the latest mainstream perspective. All of these curriculums in U.S. history research provide a new revelation. In this period, the history of curriculumhad a good interaction with the "new culture", and effectively created and promoted the curriculumhistory study's "cultural turn" theory innovation movement, and received high recognition in the field of history curriculumstudy [7]. At the same time, American curriculum culture originators thought in new period, the social crisis since the $60 \mathrm{~s}$ and the MDC had largely disappeared or were no longer so obvious, and its culture significance also gradually fade. Thus, the history of curriculum research transition development from "culture", the purpose is a response to thecultural conflict caused by American mainstream culturestructure in the new period, and on this basis explores moremeaningful cultural practice and way of life in line with the time development. In theprocess of theory innovation, education historian Cohen in University of California, Los Angeles, has not only inherited theclay progressive pursuitof his mentor, the United States education authority, but also through continuous research, made great contributions to the reality of change and innovation of the curriculum in the United States history [8].

\section{SUMMARY}

Curriculumhistory is about knowledgeform.In the study, it mainly studies how things and behavior in school and social form, activity are organically linked in detail. Curriculum history is not only all memoryofcurriculums field, but a professional one in the field, and also the extension of personal memory, an extension of educators share. To sum up, curriculumhistory, as abranch of "culture" campaign in the new period United States academic area, in terms of "market" or practice space, in the $1980 \mathrm{~s}$, curriculumhistory study "culture" transition was a success, whichplayed a certain role in promoting the progress of social culture activity in the United States and the United States curriculum study academic process.

\section{REFERENCE}

[1] Zhou Shide. American multicultural education and enlightenment in basic education of social science - based on National Social Oblique CurriculumStandard Dimension analysis [J]. Journal of Foreign Education of Primary and Secondary Schools, 2010, (3) : 18 to 21.

[2] Ye Bo. American curriculum history study orientation in 20th-century [J]. Journal of Global Education Prospects, 2012, (9) : 22-26.

[3] Trohler, D., Popkewitz, t., LabareeD. Eds. The Schooling and the Making of Citizens in the LongNIneteenth century Comparative Visions [M]. New York: edge Rout - 1. 2011.

[4] XieWenyu. "Read and write" curriculum reform-Take history and culture teaching practice in the United States for example [J]. Journal of Hunan Normal University Education Science, 2012, 11 (2) : 118-120126. 
[5] He Shanyun. The perspective of culture: the history of curriculum steering and significance [J]. Journal of education, 2014, (1): 44-49.

[6] Du Haikun, FuAnzhou, Zhang Dike. The role of American citizen education change research on citizens' cultural change--based on the perspective of historical development [J]. Journal of Hubei Academy of Social Sciences, 2012, (12): 180-183.

[7] NieYingping, FuAnzhou. Global awareness: U.S. citizen education curriculum analysis [J]. Journal of Hubei Academy of Social Sciences, 2014, (5): 176-180.

[8] Cohen, S.AnInnocentEye: The "Picto" alTurn, "Filmstudies, and History [J]. Journal of The History of Education Quarterly, lancet, 2003 (2): 250-250. The History, The Memory, The Community, inHistoricalStudies inEducation, 2004 (2): 353-361. 